\title{
ANALISIS PERILAKU BRAND SWITCHING DALAM PEMBELIAN PRODUK HANDPHONE
}

\author{
Rahmat Agus Santoso \\ Fakultas Ekonomi Universitas Muhammadiyah Gresik \\ E-mail:ra_santosa@yahoo.co.id.
}

\begin{abstract}
This study aimed to identify factors that influence consumers' brand switching behavior in the purchase of mobile products in the district Undergraduate Theses. This study uses samples of 100 respondents, the type of data used in the primary. Data collection techniques using questionnaires and multiple linear regression analysis tool. The results demonstrated that the factor of price, satisfaction and quality simultaneously and partially have influence over purchasing decisions. All three of these factors, the most dominant influence on purchase decisions is the price factor.
\end{abstract}

Keywords: price, customer satisfaction and quality.

\section{PENDAHULUAN}

Manusia dalam menjalani kehidupan mempunyai kebutuhan dan keinginan untuk dipenuhi, baik sifatnya biologis maupun psikologis. Kotler (2000) membedakan antara kebutuhan dan keinginan. Kebutuhan mendasar manusia berupa makanan, air, tempat tinggal, keamanan, penghargaan, pengakuan serta rasa kepemilikan. Keinginan (wants) adalah hasrat akan pemuas kebutuhan yang spesifik, dalam hal ini, manusia memiliki tingkatan yang berbeda terhadap produk dalam memuaskan kebutuhan dan keinginan.

Faktor kepuasan merupakan kunci untuk mempertahankan konsumen, agar membeli kembali produk dengan merk yang sama (loyal). Mowen (2002) mendefinisikan kepuasan sebagai keseluruhan sikap yang ditunjukkan konsumen atas barang atau jasa setelah memperoleh dan mengunakannya, untuk itu perusahaan dituntut mengerti apa yang sedang diinginkan oleh pasar.

Dalam perkembangan lingkungan bisnis akhirakhir ini telah memunculkan suatu gejala, yaitu semakin banyak dan beragamnya produk yang ditawarkan oleh perusahaan pada industri yang sama. Produk yang ditawarkan dapat berupa barang, jasa atau barang dan jasa untuk memenuhi kebutuhan hidup sehari-hari atau pemenuhan kebutuhan sekunder dan tersier. Beragamnya produk yang dita- warkan oleh perusahaan merupakan suatu strategi persaingan bisnis.

Krisis ekonomi yang sedang terjadi saat ini membuat persaingan suatu produk menjadi semakin ketat baik di pasar domestik maupun di pasar internasional, meskipun konsumen yang membeli selalu ada tetapi daya belinya semakin kecil. Konsumen menjadi semakin kritis untuk melakukan pembelian atas produk yang di butuhkan salah satunya handphone.

Di sisi perkembangan bisnisnya, handphone akhir-akhir ini telah menunjukkan suatu gejala, yaitu semakin banyak dan beragamnya produk handphone yang ditawarkan oleh perusahaan dan pengembangan produk handphone yang semakin cepat. Pengembangan produk handphone yang semakin cepat tersebut terletak pada bentuk, ukuran dan fasilitasnya. Semakin lama bentuk handphone semakin menarik, ukurannya semakin kecil dan fasilitas kegunaannya semakin lengkap. Saat ini banyak merek handphone yang telah beredar di Indonesia, misalnya: Nokia, Blackberry, Samsung, Sony Ericson, Siemens, LG, Philip, Motorola, Panasonic, ZTE, Smart, Taxco, Esia, Nexsian dan tiap merek meluncurkan banyak model atau seri yang bervariasi. Strategi pengembangan produk tersebut merupakan tujuan pemasar untuk menciptakan perilaku variety seeking pada diri konsumen.

Untuk memenangkan persaingan, perusaha- 
an harus mampu memberikan yang terbaik bagi pelanggannya yaitu dengan memberikan kualitas yang lebih baik, produk yang lebih murah, dan pelayanan yang lebih baik. Jika pelanggan kurang puas maka kemungkinan pelanggan akan beralih ke merek lain, hal tersebut menyebabkan turunnya angka penjualan yang diikuti berkurangnya pangsa pasar (market share) sehingga akan menurunkan laba yang dapat menimbulkan kerugian bagi perusahaan itu sendiri.

Banyak perusahaan yang telah membuktikan bahwa oleh kuatnya strategi pengembangan produk yang dilakukan merupakan tujuan pemasar untuk menciptakan perilaku mencari keragaman ( $a$ riety seeking) pada konsumen merek lain. Variety Seeking adalah perilaku dari konsumen yang berusaha untuk mencari keberagaman merek di luar kebiasaannya karena tingkat keterlibatan beberapa produk rendah.

Perilaku variety seeking menurut Kahn, Kalnawi, dan Morrison (1999) disebut juga sebagai kecenderungan individu-individu untuk mencari keberagaman dalam memilih jasa untuk mencari keberagaman dalam memilih jasa atau barang pada suatu waktu yang timbul karena beberapa alasan yang berbeda. Perilaku semacam ini sering terjadi pada beberapa produk dimana tingkat keterlibatan produk itu rendah (low involvement). Tingkat keterlibatan produk dikatakan rendah, apabila dalam proses pembuatan keputusan konsumen tidak melibatkan banyak faktor dan informasi yang harus ikut dipertimbangkan. Perilaku variety seeking ini cenderung akan terjadi pada pembelian sebuah produk yang menimbulkan risiko minimal yang akan ditanggung konsumen dan pada waktu konsumen kurang memiliki komitmen terhadap merek tertentu (Assael, 1999) perilaku variety seeking ini akan menimbulkan perilaku brand switching konsumen.

Perilaku brand switching yang timbul akibat adanya perilaku variety seeking perlu mendapat perhatian pemasar. Perilaku ini tidak hanya cenderung terjadi pada produk yang memerlukan tingkat keterlibatan yang rendah (low involve$m e n t$ ), akan tetapi terjadi juga pada produk dengan tingkat keterlibatan tinggi (high involuement). Tingkat keterlibatan produk dikatakan tinggi, apabila konsumen melibatkan banyak faktor per- timbangan dan informasi yang harus diperoleh sebelum mengambil keputusan untuk membeli.

Faktor yang termasuk dalam pertimbangan tersebut adalah risiko, yaitu risiko performance, fisik, keuangan dan waktu. Biasanya tingkat keterlibatan yang tinggi (high involvement) terjadi pada pembelian produk-produk otomotif dan elektronik (Sambandam, dalam Wulan dan Alimuddin, 2004).

Telepon genggam (handphone) atau telepon selular saat ini sudah menjadi bagian dari gaya hidup masyarakat dimana kepemilikannya tidak hanya didasarkan pada fungsi utama handphone sebagai alat komunikasi, tetapi Fitur tambahan serta desain produk juga menjadi dasar pertimbangan dalam memutuskan memilih jenis atau merek produk. Masyarakat beranggapan bahwa handphone yang dimiliknya menggambarkan status sosial pemiliknya. Memiliki handphone yang baru dan mahal menunjukkan status ekonomi yang mapan dan trend. Ada konsumen yang menganggap bahwa handphone adalah merupakan alat komunikasi, maka bentuk, fitur serta teknologi yang melengkapinya tidaklah begitu penting, masyarakat yang menggunakan handphone tipe lama sepanjang fungsinya sebagai alat komunikasi tetap berfungsi.

Handphone merupakan simbol kehidupan sehari-hari dan hampir semua orang memiliki serta menggunakannya. Handphone bukan hanya milik orang dewasa, akan tetapi juga dimiliki oleh anakanak muda dari siswa sekolah dasar, sekolah menengah sampai perguruan tinggi dan orang tua. Handphone telah merambah melintasi perbedaan strata sosial dan status ekonomi, seiring dengan semakin murahnya harga handphone serta tersedianya produk-produk second hand (barang bekas pakai) hampir tersedia di semua counter penjualan, juga adanya upaya dari beberapa provider handphone untuk melayani segmen pasar tertentu dengan harga yang dapat terjangkau.

Mengingat banyaknya pilihan merek dan tipe handphone yang ditawarkan dipasaran, serta seiring dengan perubahan selera konsumen maka tidak jarang dalam kurun waktu singkat seorang pengguna berganti merek atau tipe handphone dari suatu merek ke merek lainnya. Hal semacam itu 
menunjukkan bahwa produk handphone sangat rentan dengan perilaku variety seeking.

Beberapa faktor yang mempengaruhi pelanggan untuk loyal atau berpindah merek. Pertama adalah harga, karena harga merupakan nilai produk yang harus dibayarkan oleh konsumen. Sebagai contoh, harga yang ditawarkan suatu merek yang terlalu mahal sementara karakteristik yang ditawarkan sama dengan merek saingannya, hal semacam itu juga dapat menyebabkan perpindahan merek. Faktor yang kedua adalah ketidakpuasan, Ketidakpuasan atas produk dan merek sebagai hasil dari dua variabel kognitif antara lain harapan para pembelian dan ketidakcocokan. Terakhir adalah Kualitas produk, dimana kualitas mencerminkan kemampuan produk untuk menjalankan sesuai dengan fungsinya. apabila terdapat produk atau merek tertentu yang kualitasnya buruk atau kurang baik, maka konsumen akan enggan untuk menggunakannya dan memungkinkan untuk beralih pada produk atau merek yang lain.

Berdasarkan latar belakang masalah yang ada maka dapat dirumuskan permasalahan, yaitu apakah harga, kepuasan, dan kualitas berpengaruh secara parsial dan simultan terhadap perilaku Brand Switching pembelian Handphone? Tujuan Penelitian ini untuk mengetahui pengaruh harga, kepuasan, dan kualitas secara parsial dan simultan terhadap perilaku Brand Switching pembelian Handphone.

\section{TINJAUAN PUSTAKA}

Menurut Tjiptono (1999) harga juga dapat menentukan keputusan pembelian apabila harga yang ditetapkan harus sesuai dengan apa yang didapatkan oleh konsumen, dengan kata lain apa yang dibayar sesuai dengan apa yang didapat. Randall Ulrich dan Rebsetain (2000) mengatakan "When evaluating a product, consumers brand". Berdasarkan pendapat tersebut, ketika berbagai alternatif telah diperoleh konsumen melakukan evaluasi alternatif. Evaluasi alternatif tersebut, dalam keberadaanya ditentukan oleh keterlibatan konsumen dengan produk yang akan dibelinya. Setelah konsumen mempunyai evaluasi alternatifmakakonsumen membuat keputusan untuk membeli, dan pe- nilaian keputusan menyebabkan konsumen membentuk pilihan merek diantara beberapa merek yang tersedia.

Proses keputusan pembelian konsumen akan terjadi jika konsumen melihat kualitas produk yang diberikan memenuhi keinginan atau harapan konsumen, dan untuk mengetahui apakah kualitas produk tersebut bagus, dilihat dari fiture, reabilty, perfomence, maka konsumen akan membuat keputusan untuk membeli. Berdasarkan hal ini, maka hipotesinya adalah ada pengaruh harga, kepuasan, kualitas secara parsial dan simultan terhadap perilaku Brand Switching pembelian Handphone.

\section{METODE PENELITIAN}

Pendekatan penelitian yang digunakan dalam menyusun penelitian ini adalah pendekatan kuantitatif dengan merumuskan hipotesis yang selanjutnya dilakukan pengujian hipotesis, pengukuran data dan membuat prediksi serta mendapatkan makna dan implikasi dari suatu masalah yang ingin dipecahkan. Metode yang digunakan adalah metode assosiatif kausal. Jadi disini ada variabel independent (variabel yang mempengaruhi) dan dependent (dipengaruhi). Penelitian ini dilakukan di Kecamatan Kebomas Gresik.

Dalam penelitian ini yang menjadi populasi adalah Masyarakat Kecamatan Kebomas Gresik yang pernah melakukan Brand switching. Dalam penentuan sampel yang dipergunakan adalah non probability sampling yaitu metode penarikan sampel tanpa mengetahui peluang dari tiap responden yang akan disurvei. Teknik sampling yang digunakan adalah purposive sampling dan accidental sampling. Purposive sampling dilakukan dengan mengambil orang-orang yang terpilih menururt ciri-ciri spesifik yang dimiliki oleh sampel itu, serta dipilih secara cermat hingga relevan dengan desain penelitian. Accidental sampling adalah teknik penentu sampel berdasarkan kebetulan, yaitu siapa saja yang secara kebetulan bertemu dengan peneliti dan dapat digunakan sebagai sampel, bila dipandang cocok sebagai sumber data (Sugiyono, 2008). Menurut Roscoe dalam Sugiono (2008) ukuran sampel yang layak digu- 
nakan antara 30 sampai 100 responden. Jadi jumlah sampel yang diambil dalam penelitian ini adalah 100 orang responden.

Variabel adalah karakter atau sifat dari objek kajian yang relevan dengan permasalahan penelitian. Independent adalah suatu variabel yang menjadi pusat perhatian peneliti yang variabilitas / keragamanya merupakan suatu kondisi yang ingin diselediki. Variabel independent yang digunakan dalam penelitian ini; harga, kepuasan, dan kualitas. Dependent adalah suatu variabel yang menjadi pusat perhatian peneliti yang variabilitas / keragamanya ditentukan atau dipengaruhi variabel lainnya. Penelitian ini yang menjadi variabel terikat adalah keputusan pembelian adalah proses tahap demi tahap yang dilakukan konsumen ketika membeli barang dan jasa.

Harga adalah sejumlah uang yang harus dibayarkan oleh konsumen untuk mendapatkan suatu produk handphone. Indikator pertama, potongan harga merupakan pengurangan harga jual bagi pembeli yang telah membeli dalam jumlah besar. Kedua, harga handphone merupakan harga produk yang diperjualbelikan oleh perusahaan. Kepuasan adalah perasaan senang atau kecewa yang berasal dari perbandingan antara kesannya atau hasil kinerja suatu produk dan harapan-harapannya. Indikator pertama, keamanan pelayanan, terjadinya tingkat keamanan lingkungan. Kedua, kinerja, persepsi pelanggan terhadap apa yang konsumen terima setelah mengkonsumsi produk yang dibeli. Ketiga, harapan, perkiraan atau keyakinan pelanggan tentang apa yang akan diterimanya apabila membeli atau mengkonsumsi suatu produk. Kualitas adalah tingkat mutu yang diharapkan, dan pengendalian keragaman dalam mencapai mutu tersebut untuk memenuhi kebutuhan konsumen. Indikator pertama, fitur (keistimewaan tambahan) merupakan panggilan dan tanda sebagai karakteristik utama panggilan. Kedua, estetika merupakan bagaimana produk dilihat, dirasakan, dan didengar. Ketiga, daya tahan, merupakan umur produk. Keputusan pembelian adalah proses tahap demi tahap yang dilakukan konsumen ketika membeli barang dan jasa. Indikator pertama, pembelian handphone dapat memenuhi kebutuhan dan keinginan konsumen. Kedua, pilihan tepat. Ketiga, pembelian handphone dapat merasakan kepuasan.
Jenis data yang digunakan adalah data primer, yaitu data yang diperoleh secara langsung dari responden dengan cara pengisian kuisioner yang disesuaikan dengan karakteristik sampel yang ada. Teknik pengumpulan data yang digunakan adalah metode kuisioner, yaitu dengan cara mengajukan angket kepada responden yang berisikan daftar pertanyaan metode ini digunakan untuk mendapatkan data mengenai Brand Switching konsumen dalam pembelian Handphone.

\section{HASIL DAN PEMBAHASAN}

Responden menyatakan setuju bahwa potongan harga mempengaruhi untuk melakukan keputusan pembelian, dan sangat setuju bahwa harga handphone mempengaruhi untuk keputusan pembelian. Jadi berdasarkan variabel harga, responden menyatakan setuju bahwa sejumlah uang yang harus dibayarkan oleh konsumen untuk mendapat Handphone berpengaruh dalam keputusan pembelian.

Responden menyatakan setuju bahwa keamanan pelayanan membuat untuk melakukan keputusan pembelian, dan responden menyatakan setuju bahwa kinerja membuat untuk melakukan keputusan pembelian, serta sangat setuju bahwa harapan produk membuat untuk melakukan keputusan pembelian. Jadi berdasarkan variabel kepuasan, responden menyatakan setuju bahwa perasaan yang berasal dari perbandingan antara kesannya atau hasil kinerja.

Responden menyatakan sangat setuju fitur pada produk handphone untuk melakukan keputusan pembelian, dan setuju bahwa nilai estetika dapat mempengaruhi keputusan pembelian, serta sangat setuju bahwa daya tahan mempengaruhi keputusan pembelian. Jadi berdasarkan variabel kualitas, responden menyatakan setuju bahwa tingkat mutu yang diharapkan, dan pengendalian keragaman dalam mencapai mutu berpengaruh dalam keputusan pembelian handphone suatu produk dan harapan-harapanya berpengaruh dalam keputusan pembelian.

Responden menyatakan setuju bahwa pembelian handphone dapat memenuhi kebutuhan dan keinginan konsumen, dan setuju bahwa pembelian handphone merupakan suatu pilihan yang 
tepat, serta setuju bahwa pembelian handphone dapat merasakan kepuasan. Jadi berdasarkan variabel keputusan pembelian, responden menyatakan setuju bahwa proses tahap demi tahap yang dilakukan konsumen untuk membeli barang dan jasa.

Validitas adalah suatu ukuran yang menunjukkan tingkat-tingkat kevalidan atau kesahihan instrumen. Dalam pengujian ini digunakan analisis korelasi product moment. Untuk pengukuran validitas dilakukan dengan mengkorelasikan antara skor butir pertanyaan dengan total skor variabel, uji signifikansi atau validitas dilakukan dengan membandingkan nilai $r_{\text {hitung }}$ dengan $r_{\text {tabel }}$ dengan rumus korelasi product moment (Santoso, 2005). Uji signifikansi dilakukan dengan membandingkan nilai $r_{\text {hasil }}>r_{\text {tabel }}$, maka butir pertanyaan tersebut dikatakan valid (Ghozali, 2002). Tabel r untuk df $=\mathrm{N}-2=98$ tingkat signifikansi $5 \%$ didapat angka 0,195 .

Tabel 1. Hasil Uji Validitas Variabel Harga

\begin{tabular}{llll}
\hline Indikator & $\mathbf{r}_{\text {hasil }}$ & Sign & Keterangan \\
\hline X1.1 & 0,911 & 0,000 & Valid \\
X1.2 & 0,884 & 0,000 & Valid \\
\hline
\end{tabular}

Hasil uji validitas instrumen variabel harga menunjukkan $r_{\text {hasil }}>r_{\text {tabel }}$, maka seluruh butir pertanyaan dari variabel harga terbukti valid.

Tabel 2. Hasil Uji Validitas Variabel Kepuasan

\begin{tabular}{llll}
\hline Indikator & $\mathbf{r}_{\text {hasil }}$ & Sign & Keterangan \\
\hline X2.1 & 0,850 & 0,000 & Valid \\
X2.2 & 0,732 & 0,000 & Valid \\
X2.3 & 0,737 & 0,000 & Valid \\
\hline
\end{tabular}

Berdasarkan hasil uji validitas instrumen variabel kepuasan menunjukkan $\mathrm{r}_{\text {hasil }}>\mathrm{r}_{\text {tabel }}$, maka seluruh butir pertanyaan dari variabel kepuasan terbukti valid.

Tabel 3. Hasil Uji Validitas Variabel Kualitas

\begin{tabular}{llll}
\hline Indikator & $\mathbf{r}_{\text {hasil }}$ & Sign & Keterangan \\
\hline X3.1 & 0,783 & 0,000 & Valid \\
X3.2 & 0,716 & 0,000 & Valid \\
X3.3 & 0,859 & 0,000 & Valid \\
\hline
\end{tabular}

Berdasarkan hasil uji validitas instrumen variabel kualitas menunjukkan $r_{\text {hasil }}>r_{\text {tabel }}$, maka seluruh butir pertanyaan dari variabel kualitas terbukti valid.

Tabel 4. Hasil Uji Validitas Variabel Keputusan Pembelian

\begin{tabular}{llll}
\hline Indikator & $\mathbf{r}_{\text {hasil }}$ & Sign & Keterangan \\
\hline Y.1 & 0,737 & 0,000 & Valid \\
Y.2 & 0,855 & 0,000 & Valid \\
Y.3 & 0,832 & 0,000 & Valid \\
\hline
\end{tabular}

Berdasarkan hasil uji validitas instrumen variabel keputusan pembelian menunjukkan $r_{\text {hasil }}$ $>\mathrm{r}_{\text {tabel}}$, maka seluruh butir pertanyaan dari variabel keputusan pembelian terbukti valid.

Reliabilitas adalah ukuran yang menunjukkan konsistensi dari alat ukur dalam mengukur gejala yang sama di lain kesempatan (Santoso, 2005). Dalam penelitian ini teknik yang digunakan untuk mengukur konsistensi internal adalah koefisien alfa atau crobanch's alpha. Fungsi dari crobanch's alpha untuk mengukur tingkat reabilitas konsistensi internal diantara butir-butir pertanyaan dalam suatu instrument untuk mengukur construct tertentu (Indriantoro dan Supomo, 2002). Suatu variabel dikatakan reliabel atau handal jika jawaban seseorang terhadap pertanyaan adalah konsisten atau stabil dari waktu ke waktu. Dalam uji reliabilitas ini suatu butir atau variabel dikatakan valid jika $r_{\text {alpha }}$ $>r_{\text {tabel }}($ Santoso, 2005).

Tabel 5. Hasil Uji Reliabilitas

\begin{tabular}{lll}
\hline Indikator & Alpha & Keterangan \\
\hline Harga & 0,756 & Reliabel \\
Kepuasan & 0,664 & Reliabel \\
Kualitas & 0,693 & Reliabel \\
Keputusan pembelian & 0,736 & Reliabel \\
\hline
\end{tabular}

Tabel $\mathrm{r}$ untuk $\mathrm{df}=\mathrm{N}-2=98$ tingkat signifikansi 5\% didapat angka 0,195. Rumus (Santoso, 2005):

$R=\left[\frac{K}{K-1}\right]\left[1-\frac{\Sigma \sigma_{b}^{2}}{\sigma_{b}^{2}}\right]$

Tabel di atas menunjukkan bahwa variabel bebas dan variabel terikat mempunyai nilai $r_{\text {alpha }}$ positif dan lebih besar dari $r_{\text {tabel }}$, maka item-item 
pernyataan seluruhnya dianggap reliabel atau handal.

Persamaan regresi yang diperoleh dari analisis data harus menghasilkan estimator linear tidak terbatas atau bersifat BLUE (Best Linear Unbias Estimator) sehingga dalam pengambilan keputusan penentuan hipotesis dalam uji $t$ dan uji $F$ tidak terjadi bias. Untuk menghasilkan keputusan yang BLUE maka harus dipenuhi beberapa asumsi. Pertama, Autokorelasi. Autokorelasi artinya terdapat pengaruh dari variabel dalam model melalui tenggang waktu. Hal ini berarti bahwa nilai variabel saat ini akan berpengaruh terhadap nilai variabel lain pada masa yang akan datang. Jika dalam suatu model regresi terdapat autokorelasi maka akan menyebabkan varians sampel tidak dapat menggambarkan varians populasinya dan model regresi yang dihasilkan tidak dapat digunakan untuk menaksir nilai variabel independen tertentu. Untuk mendiagnosis ada atau tidaknya autokorelasi dalam suatu model regresi dapat dilakukan dengan cara melakukan pengujian terhadap nilai Uji DurbinWatson (Uji DW). tabel DW untuk $\mathrm{K}=3$ tingkat signifikansi 5\% didapat angka $\mathrm{dl}=1,61$ dan $\mathrm{du}=1,74$. Pengambilan keputusan ada tidaknya autokorelasi sebagai berikut:

1. Bila nilai DW terletak antara batas atas (du) dan (4-du), maka koefisien autokorelasi sama dengan nol, berarti tidak ada autokorelasi.

2. Bila nilai DW lebih rendah dari pada batas bawah (dl), maka koefisien autokorelasi lebih besar dari pada nol, berarti ada autokorelasi positif.

3. Bila nilai DW lebih besar dari pada (4-dl), maka koefisien autokorelasi lebih kecil dari pada nol, berarti ada autokorelasi negatif.

4. Bila nilai DW terletak diantara batas atas (du) dan batas bawah (dl) atau DW terletak antara (4-du) dan (4-dl), maka hasilnya tidak dapat disimpulkan.

Dari tabel Durbin Watson diketahui jumlah variabel bebas $\mathrm{K}=3$ sedangkan jumlah pengamatan 100 maka diperoleh $\mathrm{dl}=1,61$ dan $\mathrm{du}=1,74$. Nilai Hasil Durbin Watson 1,792, maka tidak ada autokorelasi.

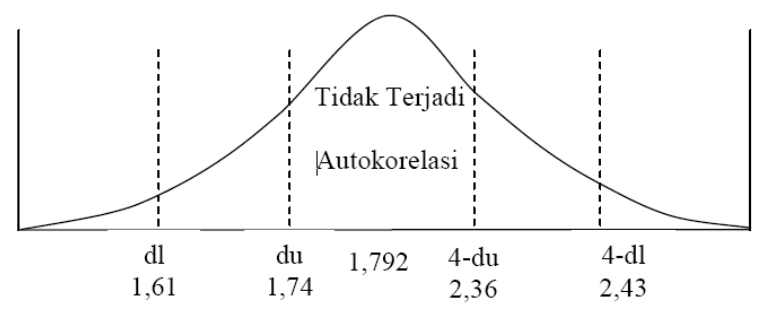

Gambar. Kuva Durbin Watson

Kedua, Multikolinearitas. Multikolinearitas artinya variabel independen yang satu dengan independen yang lain dalam model regresi saling berhubungan secara sempurna atau mendekati sempurna. Apabila pada model regresi terdapat multikolinearitas maka akan menyebabkan kesalahan estimasi akan cenderung meningkat dengan bertambahnya variabel independen, tingkat signifikasi yang digunakan untuk menolak hipotesis nol akan semakin besar dan probabilitas menerima hipotesis yang salah juga semakin besar, hal ini akan mengakibatkan model regresi yang diperoleh tidak valid untuk menaksir nilai variabel independen. Model regresi yang baik seharusnya tidak mengandung korelasi diantara variabel independen. Untuk mendeteksi ada tidaknya multikolinearitas dapat dilihat dari nilai tolerance value dan value inflation (VIF).

Apabila nilai tolerance value $<0,10$ dan VIF $>10$, maka terjadi multikolinearitas.

Jika nilai tolerance value $>0,10$ dan $\mathrm{VIF}<$ 10 maka tidak terjadi multikolinearitas.

Tabel 6. Koefisien Tolerance Value dan VIF Masing-masing Variabel

\begin{tabular}{llll}
\hline $\begin{array}{l}\text { Variabel } \\
\text { Bebas }\end{array}$ & $\begin{array}{l}\text { Tolerance } \\
\text { Value }\end{array}$ & VIF & Keterangan \\
\hline Harga & 0,460 & 2,172 & Nonmultikolinieritas \\
Kepuasan & 0,553 & 1,810 & Nonmultikolinieritas \\
Kualitas & 0,543 & 1,840 & Nonmultikolinieritas \\
\hline
\end{tabular}

Dari hasil pengelolahan data diperoleh nilai tolerance value dan VIF dari variabel bebas adalah lebih besar 0,10 dan lebih kecil dari 10, maka dapat disimpulkan bahwa model regresi tidak memiliki masalah multikolinieritas. 
Ketiga, Heteroskedastisitas. Penyimpangan asumsi model klasik yang lain adalah adanya heteroskedastisitas. Artinya, varians variabel dalam model tidak sama (konstan). Hal ini bisa diidentifikasi dengan cara melakukan Uji Glesjer, yaitu dengan meregresikan nilai absolut residual terhadap seluruh variabel bebas mempunyai nilai $t_{\text {hitung }}$ yang tidak signifikan maka dapat dikatakan bahwa model dalam penelitian lolos dari adanya heteroskedastisitas atau tidak terjadi heteroskedastisitas.

Tabel 7. Hasil Uji Glesjer

\begin{tabular}{lll}
\hline Variabel Bebas & $\mathrm{t}_{\text {hitung }}$ & Signifikan \\
\hline Harga & 0,178 & 0,859 \\
Kepuasan & $-0,538$ & 0,592 \\
Kualitas & 0,559 & 0,578 \\
\hline
\end{tabular}

Diperoleh $t_{\text {hitung }}$ semua variabel bebas terhadap nilai absolut residual tidak signifikan maka berarti tidak terjadi heterokedastisitas.

Persamaan regresi:

$\mathrm{Y}=-0,438+0,352 \mathrm{X}_{1}+0,308 \mathrm{X}_{2}+0,355 \mathrm{X}_{3}$

Nilai R square sebesar 0,564, artinya variasi dalam variabel-variabel bebas mampu menjelaskan keputusan pembelian (Y) sebesar 56,4\%. Nilai Adjusted $R$ square menunjukkan nilai 0,551 atau $55,1 \%$, ini artinya bahwa variabel-variabel bebas dalam penelitian ini harga $\left(\mathrm{X}_{1}\right)$, kepuasan $\left(\mathrm{X}_{2}\right)$ dan kualitas $\left(\mathrm{X}_{3}\right)$, mampu menjelaskan sebesar 55,1\% variasi perubahan keputusan pembelian $(\mathrm{Y})$, sedangkan sisanya sebesar 44,9\% dijelaskan oleh faktor lain yang tidak terdapat dalam model. Korelasi antara variabel-variabel bebas dengan variabel terikat sebesar $75,1 \%(\mathrm{R}=0,751)$, ini menunjukkan korelasi tersebut berada pada tahap kuat.

Untuk menguji suatu hipotesis, maka dilakukan uji statistik. Pertama, Ujit. Uji ini digunakan untuk menguji pengaruh variabel bebas (independen) terhadap variabel terikat (dependen) secara parsial.

Hipotesis yang digunakan adalah:

Ho $: \beta_{1}=0$

Maka tidak ada pengaruh yang antara variabel $\mathrm{X}$ (bebas) dan variabel Y (terikat) secara parsial
Ha: $\beta_{1} \neq 0$

Maka ada pengaruh signifikan antara variabel $\mathrm{X}$ (bebas) dan variabel Y (terikat) secara parsial

$$
t \text { hitung }=\frac{b i}{S e(b i)}
$$

Tingkat signifikansi $/ 2=0,05 / 2=0,025$ dengan $\mathrm{df}=\mathrm{n}-\mathrm{k}=97$.

Jika $t_{\text {hitung }} \geq t_{\text {tabel }}(1,9847)$, maka Ho ditolak dan Ha diterima, yang artinya ada pengaruh antara variabel X (bebas) dan variabel Y (terikat).

Jika $\mathrm{t}_{\text {hitung }}<\mathrm{t}_{\text {tabel }}(1,9847)$, maka Ho diterima dan Ha ditolak, yang artinya tidak ada pengaruh antara variabel $\mathrm{X}$ (bebas) dan variabel Y (terikat).

Berdasarkan perhitungan diperoleh $\mathrm{t}_{\text {hitung harga }}$ $(3,524)>t_{\text {tabel }}(1,9847)$ maka H0 ditolak pada tingkat signifikansi 5\% sehingga dapat diambil kesimpulan bahwa variabel harga $\left(X_{1}\right)$ berpengaruh signifikan terhadap keputusan pembelian (Y) handphone. Berdasarkan perhitungan diperoleh $t_{\text {hitung kepuasan }}(2,726)>t_{\text {tabel }}(1,9847)$ maka H0 ditolak pada tingkat signifikansi 5\% sehingga dapat diambil kesimpulan bahwa variabel kepuasan $\left(\mathrm{X}_{2}\right)$ berpengaruh signifikan terhadap keputusan pembelian (Y) handphone. Berdasarkan perhitungan diperoleh $\mathrm{t}_{\text {hitung kualitas }}(2,950)>\mathrm{t}_{\text {tabel }}(1,9847)$ maka $\mathrm{H} 0$ ditolak pada tingkat signifikansi 5\% sehingga dapat diambil kesimpulan bahwa variabel kualitas $\left(\mathrm{X}_{3}\right)$ berpengaruh signifikan terhadap keputusan pembelian (Y) handphone.

Uji F digunakan untuk menguji pengaruh variabel-variabel bebas (independen) terhadap variabel terikat (dependen) secara bersama-sama. Hipotesis yang digunakan adalah:

Ho $: \beta_{1}=0$.

Maka tidak hanya ada pengaruh yang signifikan antara variabel X (bebas) dan variabel Y (terikat) secara bersama-sama

Ha $: \beta_{1} \neq 0$.

Maka ada pengaruh yang signifikan antara variabel $\mathrm{X}$ (bebas) dan variabel Y (terikat) secara bersamasama.

Rumus (Sugiyono, 2008;192):

$$
F \text { hitung }=\frac{R /(k)}{\left(1-R^{2}\right) /(n-k-1)}
$$




\section{Keterangan:}

$\mathrm{R}=$ Koefisien regresi

$\mathrm{k}=$ Jumlah variabel independen

$\mathrm{n}=$ jumlah anggota sampel

Tingkat signifikansi $(5 \%)=0,05$ dengan $\mathrm{df}=$ $\mathrm{n}-\mathrm{k}-1=96$.

Jika $F_{\text {hitung }} \geq F_{\text {tabel }}(2,7)$, maka Ho ditolak dan Ha diterima, yang artinya ada pengaruh antara variabel $\mathrm{X}$ (bebas) dengan variabel $\mathrm{Y}$ (terikat).

Jika $\mathrm{F}_{\text {hitung }}<\mathrm{F}_{\text {tabel }}(2,7)$, maka Ho diterima dan Ha ditolak, yang artinya tidak ada pengaruh antara variabel $\mathrm{X}$ (bebas) dengan variabel $\mathrm{Y}$ (terikat).

Berdasarkan perhitungan $\mathrm{F}_{\text {hitung }} 41,468$ dengan taraf signifikansi 0,000 , maka $\mathrm{H} 0$ ditolak dan $\mathrm{H} 1$ diterima, hal ini karena $\mathrm{F}_{\text {hitung }} 41,468>$ $\mathrm{F}_{\text {tabel }}$ 2,7 dan nilai signifikansi $\mathrm{F}$ yang lebih kecil dari $0,05(0,000<0,05)$. Harga $\left(X_{1}\right)$, kepuasan $\left(\mathrm{X}_{2}\right)$ dan kualitas $\left(\mathrm{X}_{3}\right)$ secara simultan berpengaruh terhadap keputusan pembelian (Y) handphone.

Pembuktian hipotesis regresi secara parsial (uji t) ditunjukkan untuk mengetahui pengaruh masing-masing variabel bebas yang terdiri dari harga, kepuasan, dan kualitas secara parsial terhadap variabel terikat yaitu keputusan pembelian handphone. Harga mempunyai pengaruh secara parsial terhadap keputusan pembelian handphone di Kecamatan kebomas Gresik. Hasil dari pengaruh harga terhadap keputusan pembelian handphone terjadi apabila harga yang ditetapkan harus sesuai dengan apa yang didapatkan oleh konsumen, dengan kata lain apa yang dibayar sesuai dengan apa yang didapat (Tjiptono, 1999).

Kepuasan mempunyai pengaruh secara parsial terhadap keputusan pembelian handphone di kecamatan Kebomas Gresik. Kepuasan merupakan perasaan senang atau kecewa yang berasal dari perbandingan antara kesannya atau hasil kerja suatu produk dan harapan-harapannya. Menurut Randall, Ulrich dan Rebsetain (2000), Mengatakan"When evaluating a product, consumers brand'. Berdasarkan pendapat tersebut, ketika berbagai alternatif telah diperoleh konsumen melakukan evaluasi alternatif. Evaluasi alternatif tersebut, dalam keberadaanya ditentukan oleh keterlibatan konsumen dengan produk yang akan dibelinya. Setelah konsumen mempunyai evaluasi alternatif maka konsumen membuat keputusan untuk membeli, dan penilaian keputusan menyebabkan konsumen membentuk pilihan merek diantara beberapa merek yang tersedia.

Kualitas mempunyai pengaruh secara parsial terhadap keputusan pembelian handphone di kecamatan Kebomas Gresik. Tjiptono (1999) mengatakan proses keputusan pembelian konsumen akan terjadi jika konsumen melihat kualitas produk yang diberikan memenuhi keinginan atau harapan konsumen, dan untuk mengetahui apakah kualitas produk tersebut bagus, dilihat dari fiture, reabilty, perfomence, maka konsumen akan membuat keputusan untuk membeli.

Hasil uji hipotesis melalui uji F menyatakan bahwa variabel harga, kepuasan, dan kualitas secara simultan memiliki pengaruh yang signifikan terhadap keputusan pembelian handphone di kecamatan Kebomas Gresik. Harga, kualitas, kepuasan merupakan hal yang paling berpengaruh karena harga akan menjadi salah satu pilihan konsumen untuk mengunakan produk tersebut produk dengan harga yang lebih murah, fasilitas yang mudah didapatkan dan murah akan lebih diminati masyarakat, sedangkan kualitas produk akan memberikan kepuasan dan kenyamanan bagi konsumen.

\section{SIMPULAN}

Untuk meningkatkan volume penjualan pada perusahaan Handphone maka hendaknya perusahaan lebih memperhatikan faktor harga, kepuasan, kualitas. Hal ini mengingat ketiga variabel tersebut merupakan yang paling mendasar dalam menentukan keputusan pembelian.

\section{DAFTAR PUSTAKA}

Assael. 2000. Consumer Behaviour, Seventh Edition. Cincinati: Sourth Westarn Collage Publising.

Ghozali, Imam, 2002, Aplikasi Analisis Multivariate Dengan Program SPSS, Badan Penerbit Universitas Diponegoro.

Indriantoro, Nur dan Supomo, Bambang. 2002. Metodologi Penelitian Bisnis: Akuntansi dan Manajemen. BPFE. Yogyakarta. 
Kotler, Philip. 2000, Manajemen Pemasaran Penerbit Fakultas Ekonomi Universitas Indonesia.

Kotler, Philip. 2000, Manajemen Pemasaran Di Indonesia Buku 2, PT. Salemba Empat, Jakarta.

Khan,Kalnawi, dan Morrison, 1999, Manajemen Pemasaran dan Jasa, Penerbit ALFABETA, Bandung.

Mowen, 2002, Perilaku Konsumen, jilid 1 dan 2 Edisi 5, Penerbit Erlangga, Jakarta.

Randall, Ulrich, dan Rebstein. 2000. Perilaku Konsumen. Penerbit Erlangga. Jakarta.
Santoso, Singgih, 2005, Mengatasi Berbagai Masalah Dengan SPSS, Cetakan Ke Tiga, Elex Media Komputindo, Jakarta.

Sugiono, 2008, Metodologi Penelitian Bisnis, Alfabeta, Bandung.

Sugiyono, 2008, Metode Penelitian Kuantitatif Kualitatif Dan R\&D, CV ALFABETA, Bandung.

Tjiptono, 1999, Strategi Pemasaran, Edisi Dua, Cetakan Pertama, Liberty, Yogyakarta.

Wulan dan Alimuddin, 2004, Manajemen Pemasaran dan Jasa, Penerbit ALFABETA, Bandung. 